\title{
The Challenge of Globalization to American Public Law Scholarship
}

\author{
Robert Post ${ }^{*}$
}

American public law scholarship views law as a purposive instrument for the achievement of democratic purposes. It has analyzed how this instrument can best be employed within the historical context of the legal institutions and traditions of particular nation-states. Emerging forms of international law, articulated by international tribunals, challenge these fundamental premises of American public law scholarship. Much international law does not reflect the will of an indentifiable demos, and it is articulated through innovative legal institutions that combine the procedures and organizational forms of many distinct states and legal cultures. Attempting to comprehend the sources and limitations of the legitimacy of this kind of international law will force American public law scholarship to re-examine deep and implicit presuppositions, inherited from legal realism, about the inherent normativity of the rule of law. The author speculates about possible effects of this re-examination on the substantive and methodological agenda of American public law scholarship.

I have been asked to address the achievements and prospects of contemporary legal scholarship in the area of public law and human rights. This is, of course, an immense and complicated topic, far broader than anything I could reasonably cover in this brief paper. I shall be content, therefore, with a more modest ambition. I shall explore the formidable challenge to contemporary American public law scholarship posed by the recent surge of international tribunals applying forms of international law. My hope is that understanding this challenge will illuminate not only the

* Alexander F. and May T. Morrison Professor of Law, School of Law, University of California, Berkeley (Boalt Hall). 
basic intellectual orientation of current American public law scholarship, but also its intrinsic limitations.

I should note at the outset that it is somewhat awkward for an American scholar to distinguish between public and private law. We read in Black's Law Dictionary, for example, that public law consists generally "of constitutional, administrative, criminal, and international law, concerned with the organization of the state, the relations between the state and the people who compose it, the responsibilities of public officers to the state, to each other, and to private persons, and the relations of states to one another." Private law, in contrast, is said to be "[t]hat portion of the law which defines, regulates, enforces, and administers relationships among individuals, associations, and corporations." 2

As these definitions suggest, the distinction between public and private law sits most comfortably within a Continental European civil law tradition that contrasts government policies with private equities among persons. Contemporary American legal scholarship, however, has been profoundly influenced by the perspective of legal realism, which seeks to undermine precisely this contrast.

In the first third of the twentieth century, American legal realists argued that private rights between individuals should always be conceptualized as state legal interventions designed to serve ends of public policy. In response to a philosophy of substantive due process that appeared to conceive property rights as a species of natural law, the legal realists relentlessly demonstrated that rules of "private" property actually structured social relations and thus were subject to evaluation in terms of the social structures they created.

From this perspective, of course, the contrast between public and private law drops away. Government regulates social life to establish "relationships among individuals, associations, and corporations," ${ }^{3}$ and this regulation is directed toward the achievement of public goals. All private law therefore ultimately involves "the relations between the state and the people who compose it." 4

We might reformulate the difference between public and private law as one of enforcement; as a question of whether the state pursues its ends by directly mandating compliance with legal norms through its own criminal or administrative interventions or whether it decentralizes the power to initiate

\footnotetext{
Black's Law Dictionary 1230 (6th ed. 1990).

Id. at 1196.

Id.

4 Id. at 1230.
} 
such enforcement to private parties by affording them access to judicial power. In either case, the content of legal norms will express a public vision of desirable social relationships. From this point of view, therefore, there is no difference in kind between the legal norms embodied in criminal law and those embodied in contract law. They are each subject to the same forms of policy analysis.

This conclusion constitutes the great intellectual bequest of legal realism, which informs most contemporary American legal thinking. It radically distinguishes our national approach to legal analysis. In its narrow form, it is perhaps most perfectly embodied in the approach to law known as law and economics, the remarkably rapid disciplinary development of which has been a major triumph of American legal scholarship.

Law and economics explicitly and narrowly views the law as a tool for accomplishing particular social ends; it seeks to query how law can best be arranged to achieve these ends. The growing international diffusion of law and economics has spread this characteristically American perspective on the function of law. Although the scholarship of law and economics first made its mark in the area of public economic regulation exemplified by antitrust law, it has since quickly colonized subjects like contracts, which Europeans would classify as private law.

Law and economics celebrates a narrow, reductionist, and technocratic focus on the formalization of means-ends relationships, which, in turn, has spurred the development of genuine expertise about the nature and consequences of legal rules. Law and economics has not been successful, however, with respect to forms of legal purposivism that resist such formal representation. So, for example, law and economics has not had much impact on the public law I know best - constitutional law.

Although American legal scholarship regards constitutional law as purposive, as directed toward the achievement of ends, most scholars (and judges) do not sharply distinguish the ends to be achieved from the legal means for its attainment. The law is regarded as itself expressive of identity and commitment. And typically constitutional commitments are not susceptible to formal modeling, because they entail balancing among incommensurate, fundamental, but competing values. In its deepest and most profound dimensions, constitutional law is not about optimizing specific values, even the value of preference maximization, but about the construction of collective identity. As we balance, so we construct our nature as a people. In such matters, there is judgment, but not expertise.

If the purpose of constitutional law is to define, in John Marshall's 
prescient words, "the whole American fabric,"5 who should set the terms of this definition? All purposive understandings of law face a similar question. If law aspires to achieve specific ends, how and by whom are these ends to be defined? Normally, this question is answered by democratic theory, because the people, in their capacity as a demos, are conceptualized as setting the goals of law through ordinary legislative processes. But this perspective is not available in constitutional law, where the entire point is to limit the scope of otherwise valid majoritarian legislation.

American constitutional law scholarship has nevertheless striven mightily to rehabilitate the hope of democratic legitimation. Interpretative methodologies like textualism and originalism, associated with conservative figures like Scalia and Bork, seek to convert constitutional law into a direct conduit of the democratic will of the Constitution's framers and ratifiers. The ambitious reconstructive efforts of Bruce Ackerman seek to harness this project for a progressive left agenda. But although these interpretative approaches have strong theoretical appeal, they do not very well describe the actual practices of judges, who frequently must decide cases in circumstances where neither text nor original intent constitutes an especially helpful guide.

Other interpretative methodologies, therefore, have stressed the function of courts in speaking for, in the words of Oliver Wendell Holmes, "our whole experience"6 as a nation. Such methodologies have emphasized the complex interplay between courts and the articulation of a national ethos. Sometimes they take on a Burkean frame, looking to the traditions of the nation. At other times, they have a less historical orientation, focusing on the present requirements of a "living constitution."7

A roughly Burkean analysis of the relationship between courts and the national ethos, broadly understood and transposed into a procedural rather than a substantive key, is visible in the legal process school of the 1950s. It has received more recent development at the hands of scholars like Alexander Bickel and Cass Sunstein, who have focused on the institutional prerequisites of judicial legitimacy. Although this approach stresses the "countermajoritarian difficulty" by explicitly privileging the legitimacy of ordinary democratic decision-making, it nevertheless situates that legitimacy within a sensitive historical assessment of the role of judicial decision-making within American democracy. ${ }^{8}$ Analysis of the

5 Marbury v. Madison, 5 U.S. (1 Cranch) 137, 175 (1803).

6 Missouri v. Holland, 252 U.S. 416, 433 (1920).

7 For a short history of this metaphor, see Michael Kammen, A Machine That Would Go of Itself: The Constitution in American Culture 19-20 (1986).

8 See, e.g., Cass R. Sunstein, One Case at a Time: Judicial Minimalism on the Supreme 
present requirements of a "living constitution,". by contrast, has produced what is probably the dominant form of contemporary American constitutional scholarship. Exemplified by the work of figures as diverse as John Ely, Frank Michelman, and Ronald Dworkin, proponents of his approach have sought to articulate contemporary prerequisites for a truly democratic government, and they have urged courts to fashion rights in such a way as to protect these prerequisites.

All forms of American constitutional law scholarship, however, have been firmly anchored within the secure frame of a national legal system grounded in a democratic state. To a lesser but nevertheless considerable extent, the same is true of our administrative law scholarship. Much of this scholarship is about the question of ensuring democratic accountability, whether through obedience to the text of a statute enacted by a democratically-elected legislature or through fidelity to the will of democratically-elected officials responsible for enforcing the law. During the 1970s and early 1980s, American administrative scholarship focused on amplifying the democratic legitimacy of the administrative process by advocating transparency to interest group representation in administrative rule-making and decisionmaking. At all times, American administrative law scholarship has been highly sensitive to comparative analyses of institutional structure and legitimacy, considering, for example, the relative capacities of agencies and courts to acquire necessary expertise or to counter the dangers associated with capture. This work has been thoroughly (if implicitly) grounded in the local history and tradition of American legal institutions.

If constitutional law and administrative law constitute the core disciplines of American public law scholarship, the single greatest challenge to these disciplines will come from circumstances that negate the generic and implicit presupposition of this scholarship, which is the frame of a national legal system within a democratic state. I am referring, of course, to the emergence of international organizations like the WTO that purport to govern national behavior in the name of international norms and yet do not themselves have a secure anchor in a democratic legitimacy independent of constituent national legal systems. ${ }^{9}$ Such organizations typically represent unique amalgams of

Court (1999); Alexander M. Bickel, The Least Dangerous Branch: The Supreme Court at the Bar of Politics (1962).

9 For a good summary of the emergence of such international legal norms, see Patrick Tangney, The New Internationalism: Ceding Sovereign Competences to Supranational Organizations and Constitutional Change in the United States and Germany, 21 Yale J. Int'l L. 395 (1996); John C. Yoo, Globalism and the Constitution: Treaties, Non-Self-Execution, and the Original Understanding, 99 Colum. L. Rev. 1955 (1999). On the democratic deficit of such organizations, 
distinct legal traditions and institutional structures and thus cannot be analyzed on the basis of local institutional history and tradition.

The most prominent example of the creation of such an international legal regime is the European Union. EU law resists customary forms of legal analysis. It subsists in newly-created institutions that must span vastly disparate legal traditions, procedures, and assumptions, ranging from French civil law to English common law. EU law is not democratically accountable in any obvious way. Although EU regulations purport to embody "treaties" grounded in national consent, the unreality of this perspective is now commonly acknowledged; the notorious "democratic deficit" of the EU has become a cliché. ${ }^{10}$

EU legal regulation has, nevertheless, proved remarkably successful. This success is conventionally attributed to the aggressive and farsighted leadership of the Court of Justice of the European Communities (hereinafter "the ECJ"). The Court has transformed what might have been experienced as a set of merely bureaucratic impositions into what is now regarded as a genuine system of law. But without in the least minimizing the astute and perspicuous vision of the ECJ, the striking fact that I wish to emphasize in this paper is that analogous judicial decision-making seems to have become a preferred and successful route for the legitimation and implementation of international norms in many different international arenas. ${ }^{11}$

Exemplary has been the recent revival of the concept of Nuremberg-type tribunals to enforce international human rights. Like the ECJ, such tribunals are empowered to enforce a form of law that is not grounded in democratic

see Patti Goldman, The Democratization of the Development of United States Trade Policy, 27 Cornell Int'I L.J. 631 (1994); Robert F. Housman, Democratizing International Trade Decision-Making, 27 Cornell Int'l L.J. 699 (1994). For a different view, see Robert E. Hudec, 'Circumventing' Democracy: The Political Morality of Trade Negotiations, 25 Int'l L. \& Pol. 311 (1993).

10 See, e.g., Peter L. Lindseth, Democratic Legitimacy and the Administrative Character of Supranationalism: The Example of the European Community, 99 Colum. L. Rev. 628, 636-37 (1999).

11 As one commentator recently put it,

a supranational order of things will arrive incrementally, with specialized tribunals responsive to micropressures applied by domestic and transnational constituencies and interests groups. In 1998, for example, the international community established a new international criminal court. In the services sector, it makes sense to imagine the appearance of sectoralized tribunals to facilitate specific wealth-generating segments of the global service economy.

Brian F. Havel, The Constitution in an Era of Supranational Adjudication, 78 N.C.L. Rev. 257, 265 (2000). 
will and that self-consciously aspires to transcend the legal substance, traditions, and institutions of particular nation-states. The International Court of Criminal Justice recently established in the Hague, for example, will assert its legitimacy precisely as a court applying the law of international human rights. But who makes this law? Whose identity does it represent? Who sets its goals? And if, as American legal realism would suggest, the Court itself creates the law it purports to apply, by virtue of what authority does the Court speak? Without democratic warrant, it is almost as if the law and its institutions are expected to rest on their own formal authority. But exactly what is the nature of that authority? Stripped of the historically-specific institutional procedures and legal traditions of particular nation-states, what authority does naked law hold?

These questions do not arise merely in the context of international human rights. They follow in the train of many of the institutional manifestations of globalization. One need only think of the nascent arbitration procedures of the WTO or the North American Free Trade Agreement to glimpse the range of the potential application of these questions. ${ }^{12}$ They are questions that pose a profound challenge to existing American public law scholarship.

On the one hand, the legitimacy of these new international tribunals is palpable. They command respect and obedience, and their influence is growing. On the other hand, American public law scholarship lacks an intellectual framework capable of comprehending this legitimacy. It defies the assumptions that have framed most substantive constitutional and administrative law scholarship in the United States.

Because American scholarship views law as purposive, it has oriented itself around the query of whose purposes are to be given legal effect. When a specific agent, like an articulate and willful demos, cannot be located, American scholarship seeks to attribute authorship to a democratic ethos expressive of a national culture or tradition. But international law seems truly without any author, unless, of course, one is prepared to

12 On the "judicialization" of international trade relations, see Arie Reich, From Diplomacy to Law: The Juridicization of International Law, 17 Nw. J. Int'l L. \& Bus. 775, 777 (1996-1997). On the WTO, see Matthew Schaefer, National Review of WTO Dispute Settlement Reports: In the Name of Sovereignty or Enhanced WTO Rule Compliance?, 11 St. John's J. Leg. Com. 307 (1996); G. Richard Shell, Trade Legalism and International Relations Theory: An Analysis of the World Trade Organization, 44 Duke L.J. 829 (1995). On the North American Free Trade Agreement, see Demetrious G. Metropoulos, Constitutional Dimensions of the North American Free Trade Agreement, 27 Cornell Int'l L.J. 141 (1994). 
recognize the existence of a genuinely international ethos. In the context of the EU, for example, we might wish to acknowledge the presence of a European culture capable of endowing the EU with legitimate democratic warrant. But what, then, of international human rights? Is there an ethos expressive of all humanity? Or, to be less abstract, is there a genuine culture of the global marketplace capable of informing decision-making under the WTO?

A second fundamental assumption of American legal scholarship is that the expressive and functional capacities of legal institutions must be assessed against the specific historical backdrop of national traditions and professional assumptions. American scholars rely on this backdrop when they debate the relative advantages and disadvantages of locating decision-making power in courts or in administrative agencies. But international legal institutions precisely negate this backdrop. International legal institutions are sui generis; they blend the procedures and substantive premises of many different legal systems. They cannot be understood from the perspective of any single national tradition. They would thus appear to elude the forms of comparative analysis that have been a mainstay of American legal scholarship since the emergence of the legal process school.

The new global legal order seems to subsist within an almost freefloating melange of legal organizations that bootstrap their own legitimacy by virtue of rule of law values that persist independently of democratic will and of established legal institutions. That is why scholars seeking to understand this order are driven to postulate an inherent "normativity" to transnational legal processes, ${ }^{13}$ a postulate that evokes the very natural law tradition against which legal realism rebelled. It would appear, then, that the heritage of legal realism, which has proved so very generative of American public law scholarship, is helpless to assist us in comprehending these new organizations. If so, the challenge to that scholarship posed by the new legal internationalism is profound indeed.

Of course, we retain the capacity to analyze whether international legal norms can successfully achieve discrete and specific goals. We can, for example, evaluate whether the norms propagated by the new global institutions will conduce to an efficient system of international free trade. Law and economics methodology is perfectly adequate to this task. But new global institutions like the EU and the International Court of Criminal Justice also raise significant questions of legitimation and identity, questions that have obsessed American public law scholarship

13 Harold Hongju Koh, Transnational Legal Process, 75 Neb. L. Rev. 181 (1996). 
since its inception. American public law scholarship would seem without useful tools of analysis for answering these questions in the context of the new global legal order.

My guess is that American public law scholarship will respond to these dramatic issues by developing along three distinct paths. The first will focus on procedure; the second on substance; and the third on the social foundations of the rule of law. I shall discuss each of these in turn.

Within constitutional law, American legal scholarship has sometimes evaded focusing on substance by emphasizing procedure. Under the rubric of procedural due process, we have become quite adroit at analyzing the procedural requirements that ought to accompany substantive constitutional rights. I would expect a plethora of writing applying the insights of this approach to the context of international legal institutions.

Procedural reforms, however, have only limited relevance to deep questions of institutional legitimation. Even impeccable procedure, like the perfect transparency that often beguiles writing about international legal processes, cannot by itself sustain the legitimacy of a legal institution. American public law scholarship learned this lesson in the 1970s and 1980s. During that period, we directed a good deal of attention to the issue of procedural due process, to the question of which forms of procedure should be constitutionally mandated by which kinds of legal interventions. We ultimately came to understand that issues of procedure cannot substitute for analysis of underlying substantive law. ${ }^{14}$ The legitimacy of law, and the identity it asserts, do not depend upon its procedures alone.

We ought to be cautious, moreover, in uncritically translating the American scholarship of procedural due process into the quite different context of international legal institutions. American scholarship in this area was always firmly situated within American legal institutions and traditions, which will bear only limited application to the sui generis organization of international institutions. Even narrow considerations of comparative institutional expertise depend upon largely implicit assumptions concerning historical context.

I would expect, therefore, that American public law scholarship will also seek to understand the new global legal order through a reinvigorated focus on substantive rights. I say reinvigorated because in recent years,

14 Compare Cynthia R. Farina, On Misusing 'Revolution' and 'Reform': Procedural Due Process and the New Welfare Act, 50 Admin. L. Rev. 591 (1998), with Richard J. Pierce, Jr., The Due Process Counter-Revolution of the 1990s?, 96 Colum. L. Rev. 1973 (1996). 
American public law scholarship has tended to set its analysis of substantive rights within a discussion of meta-theoretical frameworks. Something extraordinary happened to American constitutional scholarship in the 1980s. We invented "constitutional theory." Constitutional theory is not about the meaning of particular constitutional rights, but, instead, about how courts ought to decide the meaning of constitutional rights. The emergence of constitutional theory was part of a more general turn to meta-theory in American legal scholarship. The first and purest expression of this turn was critical legal studies, which substituted a focus on the epistemology of law for an analysis of particular rules of law.

The rise of meta-theory was associated with a shift in the purposes of American legal academia. Traditionally, American legal scholars had oriented themselves toward judicial practice; they understood the purpose of their work to involve the clarification and analysis of the law as seen from the perspective of an appellate judge. Sometime during the late 1970s, however, this began to change. American legal scholars came increasingly to look for their validation to scholarly disciplines within the university, rather than to judges. The purpose of American public law scholarship thus began to shift away from the practical elucidation of law and toward the achievement of scholarly respectability and sophistication.

This transformation was associated with a rise in interdisciplinary legal scholarship, but the underlying point is a pragmatic one. The criteria and purposes of good legal scholarship have, for many, come to be measured by the criteria and purposes of good philosophy, or good history, or good political science, or good economics, or good cultural theory. The particular pragmatic horizon of law, which is quite different from those of these distinct scholarly disciplines, has therefore tended to recede in prominence. As a result, it has become common for judges to comment on the "irrelevance" of even the most prestigious public law scholarship.

Although constitutional theory does not reference any specific distinct scholarly discipline, it does distance itself from the practice of constitutional law as performed by judges. When asked how to decide a particular case, courts generally inquire into the meaning of the specific constitutional right at issue; they do not take a step back and seek to determine theoretically the method by which they should decide the case. Constitutional theorists, however, who are generally leaders in the world of American constitutional law scholarship, have taken the issue of interpretative methodology as the central problematic of constitutional law. They have thus created a distinct academic discipline, one that actually slights substantive analysis of particular constitutional rights.

Constitutional theory stresses the question of constitutional authorship. All 
constitutional theorists address directly the issue of democratic legitimation either through the specific will of an articulate demos or through judicial responsiveness to a national ethos. ${ }^{15}$ The form of thinking that underlies constitutional theory thus renders the new international legal institutions anomalous and opaque.

There is, however, a distinct strand of American constitutional scholarship, less prestigious than constitutional theory, that directly examines the great constitutional rights. This kind of work asks, for example, whether there should be a constitutional right to die or whether exclusion of persons from juries based upon language constitutes ethnic discrimination. Scholarship in this vein rarely turns on issues of authorship. The great constitutional rights are so thoroughly detached from either textualism or originalism, as well as from any simple or overt readings of history and tradition, that efforts to explicate their substance tend toward forms of abstract, jurisprudential analysis. Although the rights are always conceived as purposive, in the sense that they are understood to realize particular values, the question of the author of these purposes tends to be bracketed. Discussion focuses instead on the nature of the values that ought to be served.

This form of scholarship, therefore, has potential to illuminate the new international legal order. The debate within American scholarship about whether the Equal Protection Clause should be interpreted to realize an anti-discrimination principle or an anti-subordination principle, for example, could easily apply to the interpretation of anti-discrimination provisions within codifications of international human rights. The same is true of the debate within First Amendment scholarship about whether freedom of expression should be understood as promoting the autonomy of the person or as facilitating informed, democratic decision-making.

It should be stressed that American scholars discuss these questions within a set of common assumptions about what it means to enforce rights within a national judicial system. These assumptions about judicial process and power are always more or less implicitly folded into formulations of the substantive nature of a right. To American eyes, for example, international declarations of rights generally appear simultaneously overblown and under-enforced, and this combination is no accident. A right that is actually meant to be enforced must be formulated differently from a right that is meant to be purely hortatory.

It would, therefore, be a mistake to transplant uncritically American

15 See, e.g., Robert Post, Theories of Constitutional Interpretation, 30 Representations 13 (1990). 
analyses of substantive constitutional provisions into the emerging arena of international law, where judicial institutions are quite different from those in the United States. What it means to interpret and enforce international rights is evolving, which implies that the principles that should inform such rights ought as yet to remain provisional. The substantive work on such principles that has been accomplished to date, however, is certainly a good starting point for the analysis of the substantive principles of international law. My guess is that the increasing prominence of international legal norms will lead to a reemphasis of this kind of substantive public law scholarship, as distinct from the meta-theoretical emphases that have recently predominated.

A third form of American public law scholarship that I expect to be reinvigorated by the emergence of international legal institutions is the study of the rule of law itself. The rule of law does not automatically attach to legal institutions; it does not subsist in the enunciation of doctrine by persons who wear robes. Nor does it inhere in the formal properties of a system of rules; internal consistency alone will not create a rule of law. ${ }^{16}$ The best understanding of the rule of law, therefore, would describe it as a particular form of social practice that springs from a wide array of historical conditions. These conditions include legal professionalization, civil society, authoritative legal institutions, and a conceptual and institutional separation of law from politics. From this perspective, comprehending the legitimacy of international tribunals requires understanding the social prerequisites for an adequate instantiation of the rule of law.

We are accustomed to analyzing this question within the context of national legal systems in which there is a history of legal institutions and culture. A major challenge in recent human rights scholarship, for example, has been the question of how such institutions and culture can be established in the many states seeking to effect the transition from tyranny to democratic self-governance. The previous generation of human rights scholarsnip focused primarily on the articulation and enforcement of international norms. It presupposed that a rule of law existed within which these norms could be enforced. But recent human rights disasters in countries like Haiti and Cambodia, not to mention the former Yugoslavia, have rendered this presupposition palpably inadequate. As a consequence,

16 From this perspective, the reiterated assertions of transparency within international agreements and the suggestion that the rule of law might lodge in such transparency seem throwbacks to a pre-legal realist perspective. See, e.g., Yong K. Kim, The Beginnings of the Rule of Law in the International Trade System Despite U.S. Constitutional Constraints, 17 Mich. J. Int'l L. 967, 989 (1996). 
human rights scholarship must address fundamental historical, sociological, and jurisprudential questions concerning how the social prerequisites for the rule of law can be achieved. ${ }^{17}$

As difficult as these questions are, however, they pale by comparison to the challenge of situating rule of law values within newly minted international institutions. Such institutions are comprised of a melange of cosmopolitan legal professionals from a wide range of national backgrounds. Without a common history or institutions, without the frame of a traditional nation-state, exactly what can sustain the rule of law in such circumstances? ${ }^{18}$

The question is not merely academic. In the EU and elsewhere, we have witnessed the power and enormous effect of free-floating evocations of the rule of law. Understanding this power and effect and subjecting it to scholarly analysis will, I suspect, prove a major challenge to American public law scholarship in the coming decade. It will require rethinking the social preconditions of the rule of law, as well as the internal logic of systems of rules.

Some American legal scholars have addressed these questions directly; the work of Lon Fuller immediately comes to mind. But such work is distinctly marginal, and it promises to remain so. To the extent that mainstream American public law scholarship has addressed these questions, it has been through the framework of the legal process school, which, in the hands of such figures as Bickel and Sunstein, has developed into a sensitive tool of comparative institutional competence. But this perspective in part evokes powerful notions of democratic legitimation and in part rests on the specific historical traditions and practices of American institutions.

A more promising approach, therefore, lies in the viewpoint of "law and society" scholarship. This work has always been frankly nonprofessional. It has attempted to understand the social institutions of law from historical and sociological perspectives. Applied to new international legal institutions, therefore, this work would ask us to comprehend the social prerequisites of legal legitimation by evaluating the social structures that lend implicit

17 See, e.g., Carla Hesse \& Robert Post, Introduction in Human Rights in Political Transitions: Gettysburg to Bosnia (Carla Hesse \& Robert Post eds., 1999).

18 For an effort to isolate factors enhancing the legitimacy of international tribunals, see Laurence R. Helfer \& Anne-Marie Slaughter, Toward a Theory of Effective Supranational Adjudication, 107 Yale L.J. 273 (1997). 
support to claims concerning the rule of law. ${ }^{19}$ Law and society has, to date, persisted at the periphery of law school scholarship. Paradoxically, however, the strange and anomalous growth of international legal norms might push it toward the center.

19 See, e.g., Yves Dezalay \& Bryant Garth, Law, Lawyers and Social Capital: 'Rule of Law' Versus Relational Capitalism, 6 Soc. \& Legal Stud. 109 (1997). 